\title{
Genetic Diversity of the Endangered Neotropical Cichlid Fish (Gymnogeophagus setequedas) in Brazil
}

\author{
Lenice Souza-Shibatta ${ }^{1 *}$, Thais Kotelok-Diniz', Dhiego G. Ferreira ${ }^{2}$, Oscar A. Shibatta ${ }^{3}$, \\ Silvia H. Sofia' ${ }^{1}$, Lucileine de Assumpção ${ }^{4}$, Suelen F. R. Pini ${ }^{4}$, Sergio Makrakis ${ }^{4}$ and \\ Maristela C. Makrakis ${ }^{4}$ \\ ${ }^{1}$ Laboratório de Genética e Ecologia Animal, Departamento de Biologia Geral, Universidade Estadual de Londrina, Londrina, \\ Brazil, ${ }^{2}$ Laboratório de Genética e Conservação, Universidade Estadual do Norte do Paraná, Cornélio Procópio, Brazil, \\ ${ }^{3}$ Museu de Zoologia, Departamento de Biologia Animal e Vegetal, Universidade Estadual de Londrina, Londrina, Brazil, \\ ${ }^{4}$ Grupo de Pesquisa em Tecnologia em Ecohidráulica e Conservação de Recursos Pesqueiros e Hídricos - GETECH, \\ Universidade Estadual do Oeste do Paraná, Toledo, Brazil
}

\section{OPEN ACCESS}

Edited by:

Roberto Ferreira Artoni, Ponta Grossa State University, Brazil

Reviewed by:

Paulo Affonso,

Universidade Estadual do Sudoeste

da Bahia, Brazil

Charles Masembe,

Makerere University, Uganda

${ }^{*}$ Correspondence:

Lenice Souza-Shibatta lenicesouza@hotmail.com

Specialty section:

This article was submitted to Evolutionary and Population Genetics,

a section of the journal

Frontiers in Genetics

Received: 31 October 2017 Accepted: 10 January 2018

Published: 02 February 2018

Citation:

Souza-Shibatta L, Kotelok-Diniz T, Ferreira DG, Shibatta OA, Sofia SH,

de Assumpção L, Pini SFR, Makrakis S and Makrakis MC (2018) Genetic Diversity of the Endangered Neotropical Cichlid Fish

(Gymnogeophagus setequedas) in Brazil. Front. Genet. 9:13.

doi: 10.3389/fgene.2018.00013
Gymnogeophagus setequedas is a rare and rheophilic species of tribe Geophagini, considered endangered in Brazilian red lists. Its previously known geographical distribution range was the Paraná River basin, in Paraguay, and a tributary of the Itaipu Reservoir in Brazil. Since its description no specimens have been collected in the original known distribution area. However, recent records of $G$. setequedas in the lower Iguaçu River, in a region considered highly endemic for the ichthyofauna, extended the known geographical distribution and may represent one of the last remnants of the species. The aim of this study was to estimate the genetic diversity and population structure of $G$. setequedas, using microsatellite markers and mitochondrial haplotypes, in order to test the hypothesis of low genetic diversity in this restricted population. Muscular tissue samples of 86 specimens were obtained from nine locations in the Lower Iguaçu River basin, between upstream of the Iguaçu Falls and downstream of the Salto Caxias Reservoir. Seven microsatellites loci were examined and a total of 120 different alleles were obtained. The number of alleles per locus $\left(N_{A}\right)$ was 17.429 , effective alleles $\left(N_{E}\right) 6.644$, expected heterozygosity $\left(H_{E}\right) 0.675$, observed $\left(H_{O}\right)$ heterozygosity 0.592 , and inbreeding coefficient $\left(F_{I S}\right)$ 0.128. Twelve haplotypes in the D-Loop region were revealed, with values of $h(0.7642)$ and $\pi(0.00729)$, suggesting a large and stable population with a long evolutionary history. Thus, both molecular markers revealed high levels of genetic diversity and indicated the occurrence of a single $\mathrm{G}$. setequedas population distributed along a stretch of approximately $200 \mathrm{~km}$. The pattern of mismatch distribution was multimodal, which is usually ascribed to populations in demographic equilibrium. Nevertheless, the construction of a new hydroelectric power plant, already underway between the Salto Caxias Reservoir and Iguaçu Falls, could fragment this population, causing loss of genetic diversity and population decline, and for this reason it is necessary to maintain the Iguaçu River tributaries and downstream area from the Lower Iguaçu Reservoir free of additional dams, to guarantee the survival of this species.

Keywords: conservation, freshwater, Lower Iguaçu River, Gymnogeophagus, endangered species 


\section{INTRODUCTION}

The largest biodiversity asset in the world is located in Brazil (ICMBio, 2017). However, more than 1,170 species in Brazil have been classified as threatened with extinction. Unfortunately, of these, more than $26 \%$ are Actinopterygii fish found in freshwaters (ICMBio, 2017), including Gymnogeophagus setequedas Reis et al. (1992), the only one of the 17 species of the genus described so far considered as threatened (Abilhoa and Duboc, 2004; Pavanelli and Reis, 2008). This has led the Brazilian Environmental Ministry to decree the species with the status of Endangered species (EN) (decree \#445, International Union for Conservation of Nature [IUCN], 2014).

Gymnogeophagus setequedas was described based on specimens collected in tributaries of the Paraná River in Paraguay and Brazil, near the Sete Quedas region, an area currently submerged due to construction of the Itaipu Hydroelectric Power Plant (Reis et al., 1992; Pavanelli and Reis, 2008). However, since its description no specimens have been collected in the original known distribution area (Abilhoa and Duboc, 2004; Agostinho et al., 2004; Pavanelli and Reis, 2008). Nevertheless, 15 specimens of $G$. setequedas were recently collected in the Lower Iguaçu River, both up and downstream from Iguaçu Falls in the Iguaçu National Park (Paiz et al., 2017). According to the authors, finding this species in that region was quite unexpected as the Iguaçu waterfalls have lead to effective geographic isolation of the Ichthyofauna of the Iguaçu River (Zawadzki et al., 1999), providing an accentuated degree of endemicity, estimated between 51 and 71\% (Abell et al., 2008). In addition, due to its high ecological importance, the Iguaçu River basin is considered an ecoregion, separated from the rest of the Paraná River Basin (Abell et al., 2008).

The Iguaçu River basin covers an area of approximately $72,000 \mathrm{~km}^{2}$, representing part of the landscape of the three Paraná plateaus, subdivided into three regions: Upper Iguaçu (1st plateau, Curitiba region), Middle Iguaçu (2nd plateau, Ponta Grossa region), and Lower Iguaçu (3rd plateau, Guarapuava region) (Maack, 2001). The portion of the 3rd plateau that includes the Lower Iguaçu is characterized by the presence of numerous waterfalls, such as Salto Grande $(13 \mathrm{~m})$, Salto Santiago (40 m), Salto Osório (30 m), and Iguaçu Falls (Maack, 1981). The region is very attractive for hydroelectric use due to its high gradient, and, thus, the original rapids and waterfalls, have been transformed into a sequence of reservoirs that flooded approximately $656 \mathrm{~km}^{2}$, remarkably altering the landscape (Júlio Júnior et al., 1997).

It was believed that $G$. setequedas preferred lentic environments, as in the other species of the genus (Pavanelli and Reis, 2008). However, it seems that this species behaves differently from its congeners, preferring fast waters. This fact was corroborated by its recent capture in the Lower Iguaçu River, in stretches without containment and with fast waters (Paiz et al., 2017). In addition, this species disappeared after construction of the Itaipu reservoir, being collected only twice, suggesting its dependence on lotic environments (Agostinho et al., 2004). Pavanelli and Reis (2008) consider that this species no longer occurs in the Itaipu reservoir, possibly because it did not succeed in colonizing the environment formed after construction of the reservoir. In Paraguay this species is also considered an EN (Liotta, 2010), for the same reasons as in Brazil.

According to $\mathrm{Wu}$ et al. (2015), understanding the diversity and genetic structure of endangered species is fundamental to engage effective environmental conservation and management actions. Genetic diversity is essential if populations are evolving in response to environmental changes. For instance, due to the effects of anthropogenic disturbances, a small and isolated population is more likely to lose genetic diversity, and consequently present population decline, than a huge population with high genetic diversity (Frankham et al., 2010; Allendorf et al., 2012).

The genetic diversity status of species is the starting point for systematic planning of actions that should be taken to ensure the survival of species and reduce their risk of extinction. No works are known which focus on the biological (Pavanelli and Reis, 2008) or genetic diversity of $G$. setequedas. In addition, the diploid number has only recently been presented (Paiz et al., 2017). Thus, the aim of this study was to estimate the genetic diversity and population structure of G. setequedas along its recently known area of occurrence, using microsatellite markers and mitochondrial haplotypes (D-loop), thus presenting the first data of a population study of this species threatened with extinction.

\section{MATERIALS AND METHODS}

\section{Study Area and Sampling}

Our study area comprises a stretch of the Lower Iguaçu River basin, between upstream Iguaçu Falls and downstream Salto Caxias Reservoir (Figure 1).

Samples of 86 G. setequedas were collected at nine different points, some of them located in the Iguaçu National Park (PNI): two points in the main channel of the Iguaçu River (IGU 1 and IGU 2 - PNI), near the Iguaçu falls, and seven tributaries of the Iguaçu River (STO-Santo Antônio, SIL-Silva - PNI, Jardim, FLOFloriano - PNI, GON-Gonçalves Dias - PNI, CAP-Capanema, AND-Andrada, and COT-Cotegipe) (Figure 1 and Table 1). The samples were collected in 2012 (November), 2013 (November and December), and 2014 (January, February, March, April, July, August, September, November, and December). The specimens were captured using nets of different mesh sizes and electric fishing. Samples of muscle and rayed fins were taken from the fish, stored in microtubes containing $100 \%$ ethanol and kept at $-20^{\circ} \mathrm{C}$. Specimens were fixed in $10 \%$ formalin and preserved in $70 \%$ ethanol and deposited in the fish collection of the Zoology Museum at the Universidade Estadual de Londrina under catalog number: MZUEL 16332, 16353, 16354, 17094-17096.

\section{DNA Extraction and Quantification}

Total DNA was extracted from muscle or rayed fins preserved in 95\% EtOH following the phenol/chloroform protocol of Almeida et al. (2001). NanoDrop ${ }^{\text {TM }} 1000$ was used for determination of DNA concentrations and samples were diluted in ultrapure water, 


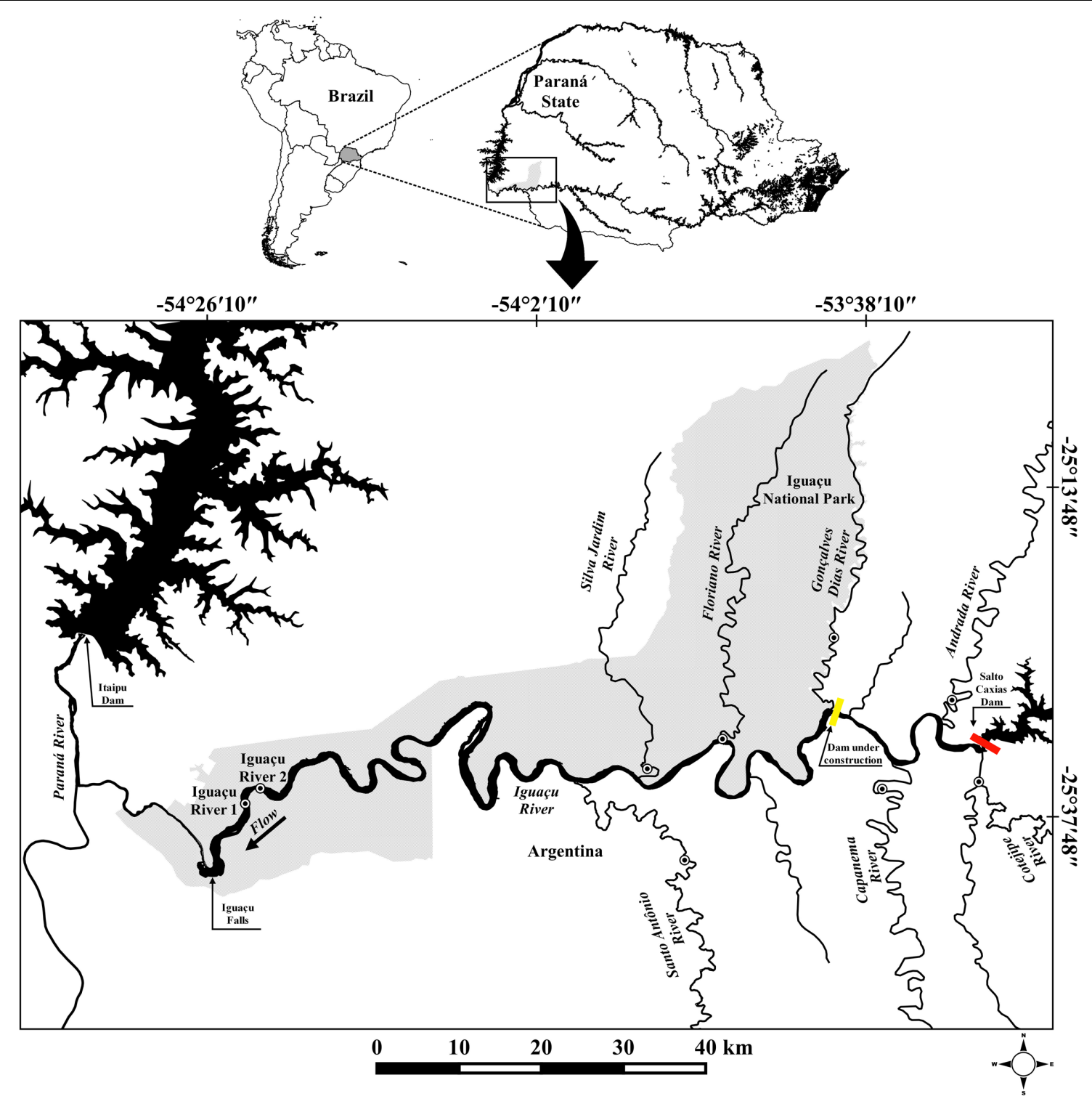

FIGURE 1 | Map of southern South America showing collection points (dotted circle) of Gymnogeophagus setequedas. The yellow bar represents the Baixo Iguaçu Hydroelectric Power Plant under construction, and red bar indicates Salto Caxias Hydroelectric Power Plant.

$10 \mathrm{ng} / \mu \mathrm{L}$ for microsatellite markers and $5 \mathrm{ng} / \mu \mathrm{L}$ for $\mathrm{mtDNA}$ D-loop markers.

\section{Microsatellite Amplification and Genotyping}

Cross-amplification tests were conducted from seven loci described for Geophagus brasiliensis (Gbra6, Gbra16, Gbra17, Gbra62, Gbra63, Gbra80, and Gbra96) (Ferreira et al., 2013). Reagent concentrations and PCR conditions were performed according to Ferreira et al. (2015), using the modifications proposed by Schuelke (2000). PCR thermal conditions were conducted as follows: initial denaturation step at $94^{\circ} \mathrm{C}$ for $4 \mathrm{~min}$, followed by 35 cycles of denaturation at $94^{\circ} \mathrm{C}$ for $40 \mathrm{~s}$. The annealing temperatures of successful cros-amplifications loci were $48^{\circ} \mathrm{C}$ (Gbra16, Gbra62, Gbra63, Gbra80), 54 ${ }^{\circ} \mathrm{C}$ (Gbra06, Gbra17, Gbra70), or $60^{\circ} \mathrm{C}$ (Gbra96) for $1 \mathrm{~min}$, extension at $72^{\circ} \mathrm{C}$ for $1 \mathrm{~min}$, followed by a final extension at $72^{\circ} \mathrm{C}$ for 30 min. PCR products were analyzed on an ABI PRISM 3500-XL automated sequencer (Applied Biosystems) using GeneScan 600 Liz (Applied Biosystems) as a molecular weight marker.

\section{mtDNA (D-Loop) Marker}

Part of the control region (D-loop) of the $G$. setequedas mitochondrial DNA was amplified using PCR. The primers used were L 5'-AGAGCGTCGGTCTTGTAAACC-3' (Cronin et al., 1993) and H 5' -CTGAAGTAGGAACCAGATG-3' (Meyer et al., 1990). PCR reactions were performed in a $25 \mu \mathrm{L}$ final volume containing 1X GoTaq Master Mix (Promega), $1 \mu \mathrm{M}$ 
TABLE 1 | Sampling sites for Gymnogeophagus setequedas, including sample sizes per site $(\mathrm{N})$ and location.

\begin{tabular}{|c|c|c|c|}
\hline $\begin{array}{l}\text { Collection } \\
\text { point }\end{array}$ & $N$ & $\begin{array}{l}\text { Specific } \\
\text { collecting } \\
\text { location }\end{array}$ & Geographic coordinates \\
\hline$(1)-(\mid \mathrm{GU} 1)$ & 02 & Iguaçu River 1 & $25^{\circ} 35^{\prime} 43.79^{\prime \prime} \mathrm{S} 54^{\circ} 22^{\prime} 17.51^{\prime \prime} \mathrm{W}$ \\
\hline (2) - (IGU 2) & 50 & Iguaçu River 2 & $25^{\circ} 36^{\prime} 50.77^{\prime \prime} \mathrm{S} 54^{\circ} 23^{\prime} 23.42^{\prime \prime} \mathrm{W}$ \\
\hline (3) - (STO) & 25 & $\begin{array}{l}\text { Santo Antônio } \\
\text { River }\end{array}$ & $25^{\circ} 40^{\prime} 57.60^{\prime \prime} \mathrm{S} 53^{\circ} 51^{\prime} 22.91^{\prime \prime} \mathrm{W}$ \\
\hline (4) - (SIL) & 01 & $\begin{array}{l}\text { Silva Jardim } \\
\text { River }\end{array}$ & $25^{\circ} 34^{\prime} 18.64^{\prime \prime} \mathrm{S} 53^{\circ} 54^{\prime} 06.13^{\prime \prime} \mathrm{W}$ \\
\hline (5) - (FLO) & 01 & Floriano River & $25^{\circ} 32^{\prime} 08.12^{\prime \prime} \mathrm{S} 53^{\circ} 48^{\prime} 37.46^{\prime \prime} \mathrm{W}$ \\
\hline (6) - (GON) & 02 & $\begin{array}{l}\text { Gonçalves Dias } \\
\text { River }\end{array}$ & $25^{\circ} 24^{\prime} 45.53^{\prime \prime} \mathrm{S} 53^{\circ} 40^{\prime} 30.30^{\prime \prime} \mathrm{W}$ \\
\hline$(7)-(\mathrm{CAP})$ & 01 & $\begin{array}{l}\text { Capanema } \\
\text { River }\end{array}$ & $25^{\circ} 35^{\prime} 46.76^{\prime \prime} \mathrm{S} 53^{\circ} 36^{\prime} 58.98^{\prime \prime} \mathrm{W}$ \\
\hline (8) - (AND) & 03 & Andrada River & $25^{\circ} 29^{\prime} 18.17^{\prime \prime} \mathrm{S} 53^{\circ} 31^{\prime} 54.16^{\prime \prime} \mathrm{W}$ \\
\hline (9) - (COT) & 01 & Cotegipe River & $25^{\circ} 35^{\prime} 15.39^{\prime \prime} \mathrm{S} 53^{\circ} 29^{\prime} 57.11^{\prime \prime} \mathrm{W}$ \\
\hline
\end{tabular}

of each primer, $15 \mathrm{ng}$ DNA, and ultrapure water to volume. The thermal profile included an initial denaturation at $94^{\circ} \mathrm{C}$ for $4 \mathrm{~min}$, followed by 41 cycles at $94^{\circ} \mathrm{C}$ for $15 \mathrm{~s}$, annealing at $56^{\circ} \mathrm{C}$ for $30 \mathrm{~s}$, and extension at $72^{\circ} \mathrm{C}$ for $2 \mathrm{~min}$, with a final extension at $72^{\circ} \mathrm{C}$ for $10 \mathrm{~min}$. The PCR products were purified using ExoSAP IT (Prodimol Biotecnologia S.A, Belo Horizonte, Minas Gerais, Brazil). The Big Dye Terminator v 3.1 kits (Applied Biosystems) and ABI-PRISM 3500 XL automated sequencer (Applied Biosystems) were used for sequence analysis. Multiple alignment analysis was carried out using the ClustalW application (Thompson et al., 1994) in BioEdit 7.1.3.0 (Hall, 1999). NCBI's BLAST search (Basic Local Alignment Search Tool, Altschul et al., 1990) was used to confirm the origin of the fragment. To search for possible tRNA, was used an online version of the tRNAscan-SE (Lowe and Eddy, 1997), available at http://lowelab.ucsc.edu/tRNAscan-SE. Sequences of the 12 different haplotypes were deposited in GenBank (MG581478 to MG581489).

\section{Genetic Analyses (Microsatellites) Population Structure}

The first step for genetic analyses was to define the number of existing populations. For this we used population analyzes based on Bayesian approaches that mainly include "attribution methods." These methods calculate the probability of the different genotypes being observed in each population and assign the individuals to the populations according to the possibilities of the genotypes belonging to them, without any a priori inference. Thus, such analyzes allow to infer which population an individual belongs to, regardless of their collection site (Beaumont and Rannala, 2004).

In order to evaluate the relationship between samples, we conducted a Bayesian cluster analysis of the population by using STRUCTURE v.2.3.3 (Pritchard et al., 2000) program. The number of populations $(K)$ was estimated by using the admixture model and correlated allele frequencies among populations, with $K$ ranging from 1 to $10(K=1-10)$
(Evanno et al., 2005). A total of 20 independent runs of 100,000 Markov Chain Monte Carlo (MCMC) iterations discarded as burn-in, followed by 1,000,000 MCMC iterations were used for each value of $K$. The best-fit number of groupings was evaluated using $K$, ln $\operatorname{Pr}(\mathrm{X} / K)$ (Pritchard et al., 2000) and $\Delta K$ ad hoc statistics (Evanno et al., 2005) by Structure Harvester v.0.6.7 (Earl and VonHoldt, 2012). Graphs representing the membership coefficient of each sampled individual were plotted using Distruct 1.1 (Rosenberg, 2004). Genetic differentiation estimates were assessed from pairwise $\Phi_{\text {ST }}$ values obtained in ARLEQUIN v.3.5.1.3 (Excoffier and Lischer, 2010). Significant estimates were based on 10,000 permutations. Subsequently, $P$-values corresponding to alpha $=0.05$ were adjusted after Holm-Bonferroni correction for multiple tests (Holm, 1979).

\section{Genetic Diversity}

Number of alleles per locus $\left(N_{\mathrm{A}}\right)$, effective number of alleles $\left(N_{\mathrm{E}}\right)$, expected and observed heterozygosity $\left(H_{\mathrm{O}}, H_{\mathrm{E}}\right)$ were obtained with POPGEN v. 1.31 (Yeh et al., 2000) software. Inbreeding coefficient $\left(F_{\text {IS }}\right)$ was obtained with Fstat v2.9.3 program (Goudet, 2001). Deviation from Hardy-Weinberg equilibrium (HWE) and the linkage disequilibrium between pairs of loci with significance $(P$-value), later adjusted by the Bonferroni sequential correction (Rice, 1989) were tested with the GENEPOP v.1.2 (Raymond and Rousset, 1995). MICRO-CHECKER 2.2.1 (Van Oosterhout et al., 2004) software was used to test for the possible presence of null alleles or other genotyping errors such as allelic dropout and reading errors due to stutter peaks.

\section{Gene Flow}

The contemporary migration rates over a few previous generations and the direction of migration among the samples studied, was estimated by using the BayesAss v 3.0.3 program (Wilson and Rannala, 2003), at 95\% confidence intervals. Ten runs were analyzed using different random starting seed numbers, with 3,000,000 MCMC iterations, including 999,999 discarded burn-in iterations. After the burn-in, every 2000th iteration was sampled. The delta values (maximum amount by which parameter values are allowed to change between iterations) were 0.15 for allele frequencies, 0.025 and 0.05 for migration rate, and 0.15 for inbreeding value.

\section{Demographic Analyses}

Recent population bottleneck signs were evaluated on microsatellite data using Bottleneck v.1.2.02 program (Piry et al., 1999), considering deviations from the mutation-drift equilibrium. Three tests were used, including two tests to indicate bottlenecks in the presence of significant excess heterozygosity: "Sign test" (Cornuet and Luikart, 1996) and the "Wilcoxon sign-rank test" (Luikart and Cornuet, 1998), both based on the Infinite Alleles Model (IAM), Stepwise Mutation Model (SMM), and Two-Phase Model (TPM - with 90\% SMM and 10\% IAM), with a $P$-value $<0.05$. The third test was the "Mode shift test" that indicates bottlenecks resulting from alterations in allele frequency distributions (Luikart et al., 1998). 


\section{Genetic Analyses (mtDNA) Genetic Diversity}

Haplotype number, haplotype diversity $(h)$ and nucleotide diversity $(\pi)$ were obtained from DnaSP v.5 program (Librado and Rozas, 2009). Arlequin v.3.5.1.3 program (Excoffier and Lischer, 2010) was used to conduct the selective neutrality tests based on the infinite sites model of Tajima (D) (Tajima, 1989) and $\mathrm{Fu}(\mathrm{Fs})(\mathrm{Fu}, 1997)$. The Network v.4.6.1.1 program (Fluxus Technology Ltd. $^{1}$ ) was used to construct haplotype networks from mtDNA data based on the median-joining algorithm (Bandelt et al., 1999).

\section{RESULTS}

\section{Population Structure}

Bayesian clustering analysis (Structure) applied to microsatellite data indicated that the most probable $K(K+$ cluster number) was $K=1$, from $\ln \operatorname{Pr}(X / K)$. The graphic representation of $\Delta K$ showed that there were no well-defined groups, the ancestral values were distributed homogeneously among individuals and samples, indicating the occurrence of a single $G$. setequedas population (Figure 2A). Molecular Variance Analysis (AMOVA), conducted for all samples showed very little variation among them $\left(\Phi_{\mathrm{ST}}=0.025, P>0.05\right)$. Following this result, all other analyzes were based on a single population.

${ }^{1}$ http://www.fluxus- engineering.com

\section{Genetic Diversity}

In the entire sample, a total of 120 different alleles were obtained from seven microsatellite loci. The number of alleles per locus $\left(N_{\mathrm{A}}\right)$ was 17.429, effective alleles $\left(N_{\mathrm{E}}\right) 6.644$, expected heterozygosity $\left(H_{\mathrm{E}}\right) 0.675$, observed $\left(H_{\mathrm{O}}\right)$ heterozygosity 0.592 , and inbreeding coefficient $\left(F_{\text {IS }}\right) 0.128$.

After applying the Bonferroni sequential correction, there were no significant deviations $(P<0.05)$ in the HardyWeinberg equilibrium (HWE) at the majority of microsatellite loci, only the locus Gbra96 showed significant deviation. This correction was also applied to the linkage disequilibrium (LD) tests, and a significant value was found only in locus Gbra96. The Micro-Checker program found no null alleles among the samples.

From the amplification and sequencing of mtDNA of 82 G. setequedas individuals, a $449 \mathrm{bp}$ fragment from the D-loop region was obtained. Twenty polymorphic sites (17 transition and three transversion mutations) and four indels sites were found. Twelve different haplotypes were revealed, of which four haplotypes (H5, H7, H10, and H12) were singletons (Figure 2B). The $\mathrm{H} 2$ haplotype was the most frequent, observed in 37 samples from four different locations (IGU1, IGU2, STO, and FLO). Although SIL, FLO, GON, COT, and CAP present only one haplotype each, these haplotypes are shared with other locations, except for H5 found only in CAP. The IGU2 has the highest number of haplotypes $(N=8)$, followed by STO $(N=6)$, AND $(N=3)$, and IGU1 $(N=2)$. Haplotype $(h)$ and nucleotide $(\pi)$ diversity values were 0.7642 and 0.00729 , respectively (Table 2 ).
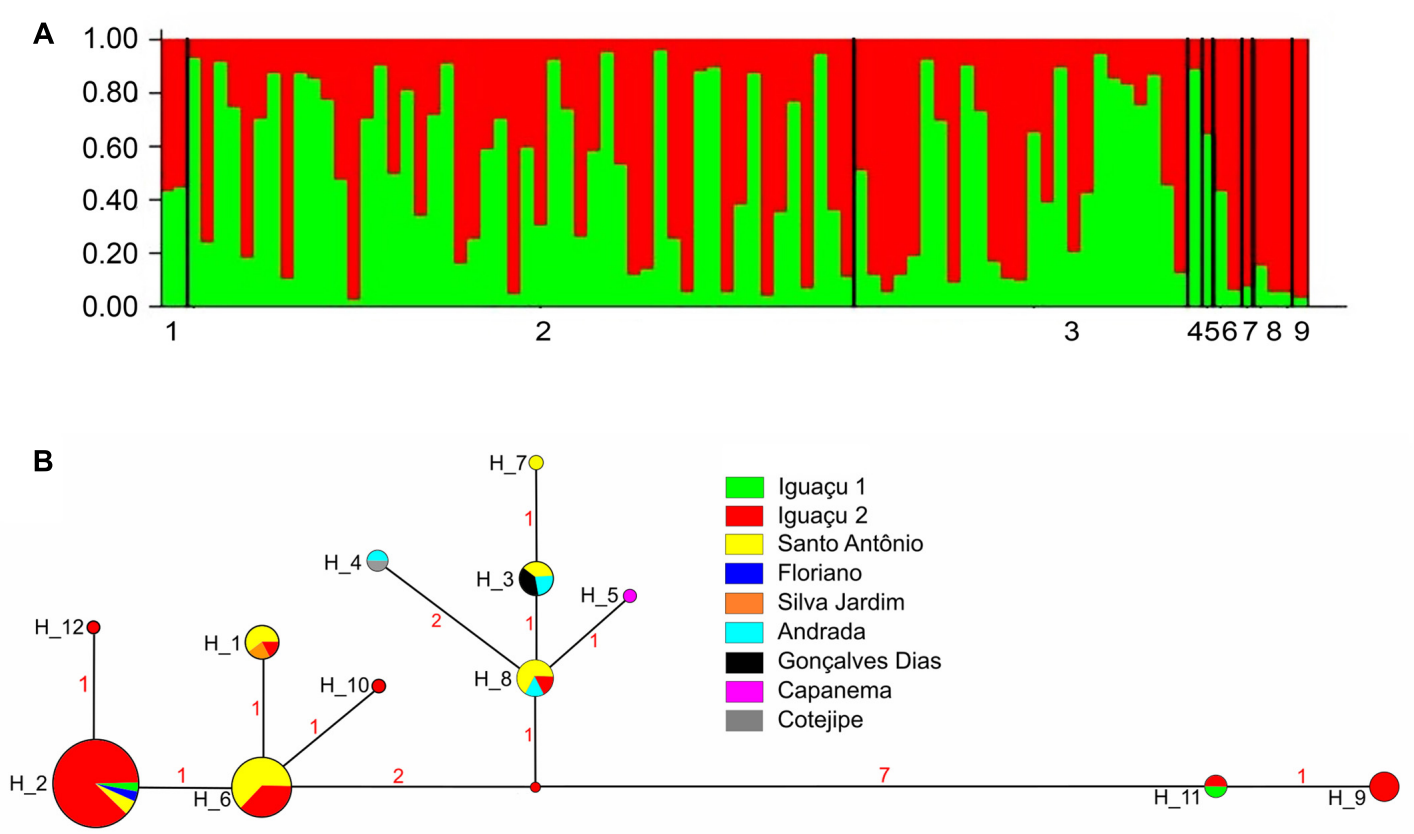

FIGURE 2 | (A) Graphical representation of Bayesian cluster analysis from $K=1$. Each column represents a different individual of G. setequedas, and the colors represent the probability of the ancestral coefficient of individual in each genetic cluster. Numbers represent the collection points: (1) Iguaçu 1; (2) Iguaçu 2; (3) Santo Antônio; (4) Silva Jardim; (5) Floriano; (6) Gonçalves Dias; (7) Capanema; (8) Andrada; (9) Cotegipe. (B) Haplotype network based on partial sequencing of the D-loop region (mtDNA) of 82 individuals of $G$. setequedas from the Lower lguaçu River. Circle sizes are proportional to haplotype frequency. Numbers between haplotypes denote mutational steps between sequences. 


\section{Demographic Analyses}

The signed-rank test did not produce significant values in any of the mutational models (IAM, SSM, or TPM). In the mode-shift test, the samples showed typical L-shaped distribution (nonbottleneck) in the frequency of the alleles in the mode-shift test (Table 3). The mismatch distribution graphic demonstrated a multimodal distribution for haplotypes (Figure 3), which is usually ascribed to populations in demographic equilibrium. In the neutrality tests, Tajima test values $(D)$ and Fu test values $\left(F_{\mathrm{s}}\right)$ were negative and not significant (Table 2).

\section{Gene Flow}

Bayesian gene flow analysis of the microsatellite data revealed contemporary migration values among the samples within the confidence interval (95\%). Values for non-immigrants in each sample, ranging from 79 to $82.6 \%$. However, migration estimates were also obtained and showed similar values among the majority of samples. The lowest migration estimates were from IGU 1 to COT and IGU 2 to AND, both with $1.9 \%$. On the other hand, the highest migration values were from FLO to IGU2, and to GON, and COT to CAP, with $2.7 \%$. Among all the samples, FLO was the one that obtained the highest percentage of migrants, for the largest number of sites (Table 4).

\section{DISCUSSION}

\section{Genetic Diversity and Population Structure}

The study of molecular markers, such as Microsatellite and mtDNA, generates important information on the genetic variation and structure of fish species and is a significant step toward realizing the goal of conservation of species in their natural populations (Carvalho-Costa et al., 2008; Piorski et al., 2008; Garcez et al., 2011; Abdul-Muneer, 2014). According to $\mathrm{Wu}$ et al. (2015), understanding the diversity and genetic structure of endangered species are essential to engage effective environmental conservation and management action. The longterm persistence of species depends on sufficient genetic diversity to adapt and survive in variable or changing environments (Hughes et al., 2008).

According to DeWoody and Avise (2000), based on a metaanalysis of microsatellite polymorphisms, freshwater fish, on average, have $9.1 \pm 6.1$ alleles and expected heterozygosity of $0.54 \pm 0.25$ per population. Therefore, based on microsatellites, the genetic diversity of the G. setequedas population in terms of allele numbers (17.14) and the expected heterozygosity (0.67) are as expected for freshwater fish. In addition to the high diversity in the nuclear markers, the G. setequedas analyzed showed significant variations in mitochondrial DNA, exhibiting high levels of genetic diversity. According to Freeland (2005), $h$ is considered the haploid equivalent of HE in data on diploids. The similarity among these estimates suggests that the current variations in nuclear and mitochondrial DNA are evenly distributed throughout G. setequedas population.

A high level of genetic diversity is an important attribute for species and may confer the basis for adaptation to environmental change (Piorski et al., 2008), especially when it comes to endangered species such as G. setequedas (Abilhoa and Duboc, 2004; Pavanelli and Reis, 2008; International Union for Conservation of Nature [IUCN], 2014).

\section{Demographic History}

A $449 \mathrm{bp}$ test in the D-Loop region, one of the most variable regions of mtDNA (Frankham et al., 2010), revealed 12 haplotypes and high values of $\pi(0.00729)$ and $h(0.750)$. In addition, analysis of the microsatellite data using Bottleneck program showed no significant recent bottlenecks. The absence of recent bottlenecks is corroborated by the high haplotype $(h>0.5)$ and nucleotide diversity $(\pi>0.5 \%)$ values in the mtDNA. According to Grant and Bowen (1998), high haplotypic diversity combined with high nucleotide diversity represents a

TABLE 2 | Genetic diversity of G. setequedas in the Lower lguaçu River basin, based on microsatellite markers and mitochondrial haplotypes (D-Loop).

\begin{tabular}{|c|c|c|c|c|c|c|c|c|c|c|c|c|}
\hline \multicolumn{7}{|c|}{ Microsatellites } & \multicolumn{6}{|c|}{ mtDNA } \\
\hline$N$ & $A$ & $\mathbf{N}_{\mathbf{A}}$ & $\bar{N}_{\mathrm{E}}$ & $H_{0}$ & $H_{\mathrm{E}}$ & $F_{\text {IS }}$ & $N$ & Nh & $\boldsymbol{h}$ & $\pi$ & $D$ & $\boldsymbol{F}_{\mathrm{S}}$ \\
\hline 86 & 120 & 17.143 & 6.574 & 0.593 & 0.673 & 0.126 & 82 & 12 & 0.7642 & 0.00729 & -0.570 & -0.285 \\
\hline
\end{tabular}

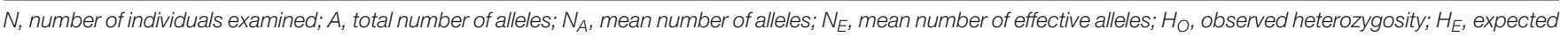
heterozygosity; FIS, inbreeding coefficient; Nh, number of haplotypes; $h$, haplotype diversity; $\pi$, nucleotide diversity; D, Tajima's neutrality test; Fs, Fu's neutrality test.

TABLE 3 | Bottleneck tests in 86 samples of G. setequedas from the Lower lguaçu River Basin.

Sign test/Wilcoxon sign-rank test

Allele frequency distribution

\begin{tabular}{|c|c|c|c|c|c|c|c|c|}
\hline & \multirow[b]{2}{*}{$N$} & \multicolumn{2}{|c|}{ IAM $^{\mathbf{a}}$} & \multicolumn{2}{|c|}{ TPM $^{b}$} & \multicolumn{2}{|c|}{$\mathrm{SMM}^{\mathrm{c}}$} & \\
\hline & & $H_{\mathrm{d}} / H_{\mathrm{e}}$ & $P$ & $H_{\mathrm{d}} / H_{\mathrm{e}}$ & $P$ & $H_{\mathrm{d}} / H_{\mathrm{e}}$ & $P$ & \\
\hline Total & 86 & $3 / 4$ & 0.710 & $6 / 1$ & 0.996 & $7 / 0$ & 1.000 & L-shaped \\
\hline
\end{tabular}

$\mathrm{N}$, number of individuals; $H_{e}$, number of loci exhibiting excess heterozygosity; $H_{d}$, number of loci exhibiting deficient heterozygosity. Normal L-shaped distribution = nonbottlenecked population. alnfinite allele model, ${ }^{\mathrm{b}}$ two phase model, ${ }^{\mathrm{c}}$ stepwise mutation model. 


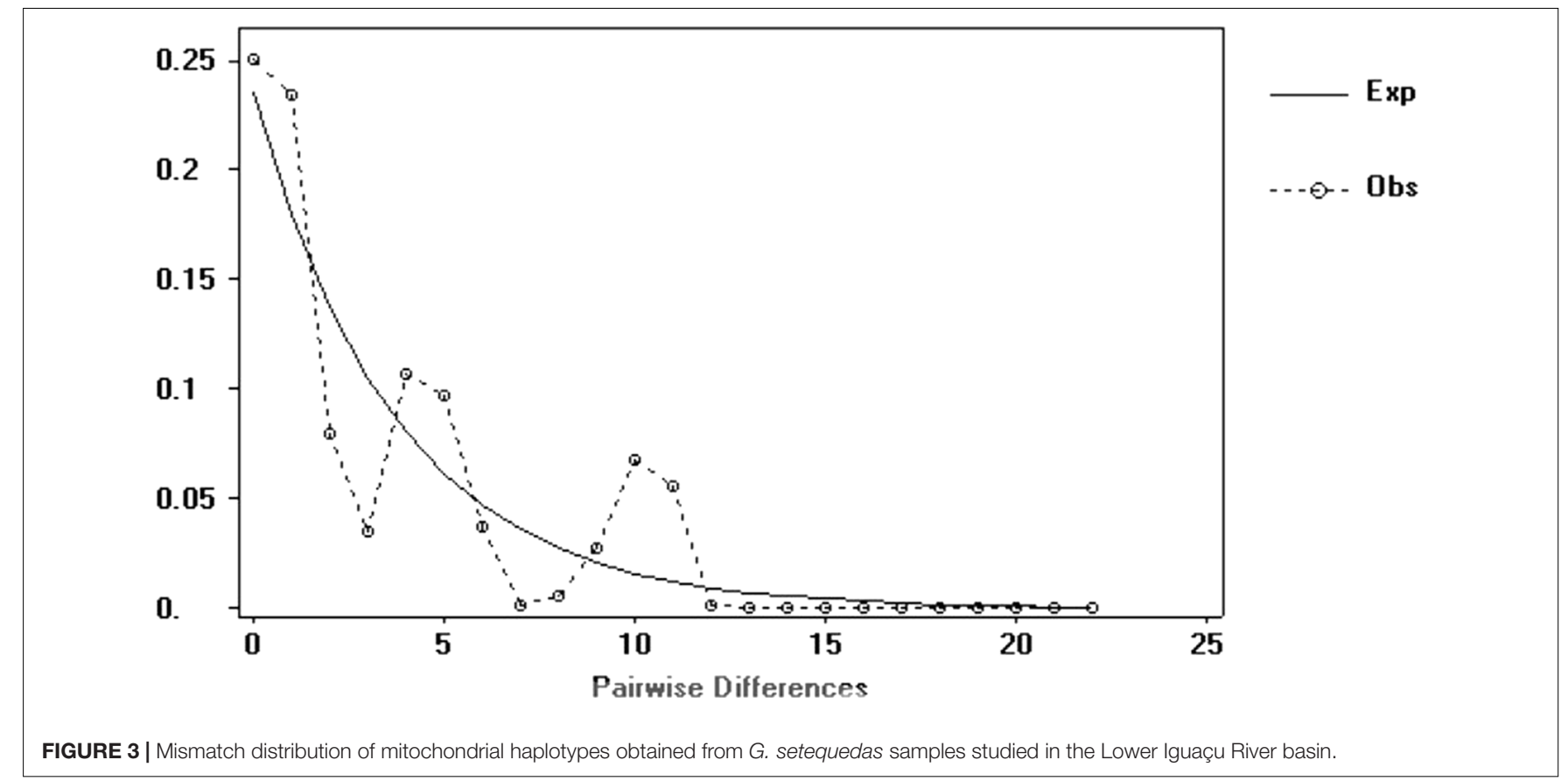

large and stable population with a long evolutionary history, or secondary contact between different lineages. Stable population with a long evolutionary history seems to be a very plausible possibility for G. setequedas, as the Iguaçu waterfalls have exerted effective geographic isolation on ictiofauna of the Iguaçu river (Zawadzki et al., 1999), providing an accentuated degree of endemicity, of more than 70\% (Abell et al., 2008). In addition, analysis of the distribution of substitution differences between pairs of haplotypes (mismatch distribution) (Cunha and SoléCava, 2012) shows multimodal distributions, which is generally attributed to populations in demographic equilibrium (Rogers and Harpending, 1992).

However, negative values in the Tajima's $D$ test and Fu's $F_{\mathrm{s}}$ test, even if not significant, could suggest population expansion after an ancient bottleneck (Slatkin and Hudson, 1991; Grant and Bowen, 1998), indicating that all the current haplotypes are closely related and derived from a single main haplotype (H2). Signs of old bottlenecks may be less evident at microsatellite loci, since they tend to recover from the variation more rapidly than mitochondrial sequences. At the same time, $\pi$ recovery after a genetic bottleneck is slower than $h$ at mtDNA (McCusker and Bentzen, 2010).

\section{Gene Flow}

The individuals of the Floriano River (FLO) presented the highest rates of migration, and the highest levels of admixture in samples were found in the Iguaçu 2 and Gonçalves Dias rivers. The specimens from rivers further upstream in the drainage (FLO, GON, CAP, and COT) appear to have more levels of admixture between them. This factor might suggest that entry into the upper tributaries is more likely than the lower. However, the highest rates of migrants to Iguaçu 1 are from most upstream tributaries, suggesting that populations of $G$. setequedas maintain satisfactory gene flow in all stretches of the river studied. According to Palstra and Ruzzante (2008), if local populations are small, as is the case in the present study, gene flow is the key factor to prevent the

TABLE 4 | Gene flow estimates based on Bayesian inferences of migration rates using BayesAss.

\begin{tabular}{|c|c|c|c|c|c|c|c|c|c|}
\hline Migration & IGU 1 & IGU 2 & STO & SIL & FLO & GON & CAP & AND & COT \\
\hline IGU 1 & $82.6 \%$ & $2.2 \%$ & $2 \%$ & $2.1 \%$ & $2.6 \%$ & $2.4 \%$ & $2.4 \%$ & $2.4 \%$ & $2.4 \%$ \\
\hline IGU 2 & $2.1 \%$ & $82.2 \%$ & $2.2 \%$ & $2.1 \%$ & $2.7 \%$ & $2.2 \%$ & $2.5 \%$ & $2.5 \%$ & $2.5 \%$ \\
\hline STO & $2 \%$ & $2.3 \%$ & $81.5 \%$ & $2.3 \%$ & $2.3 \%$ & $2.4 \%$ & $2.4 \%$ & $2.4 \%$ & $2.4 \%$ \\
\hline SIL & $2.2 \%$ & $2.4 \%$ & $2.5 \%$ & $81.7 \%$ & $2.6 \%$ & $2.4 \%$ & $2.4 \%$ & $2.4 \%$ & $2.4 \%$ \\
\hline FLO & $2 \%$ & $2.2 \%$ & $2.2 \%$ & $2.3 \%$ & $79 \%$ & $2.4 \%$ & $2.6 \%$ & $2.4 \%$ & $2.5 \%$ \\
\hline GON & $2.2 \%$ & $2.2 \%$ & $2.4 \%$ & $2.3 \%$ & $2.7 \%$ & $80.7 \%$ & $2.6 \%$ & $2.5 \%$ & $2.6 \%$ \\
\hline CAP & $2.2 \%$ & $2.2 \%$ & $2.4 \%$ & $2.2 \%$ & $2.5 \%$ & $2.4 \%$ & $79.7 \%$ & $2.6 \%$ & $2.7 \%$ \\
\hline AND & $2.4 \%$ & $1.9 \%$ & $2.1 \%$ & $2.4 \%$ & $2.5 \%$ & $2.4 \%$ & $2.3 \%$ & $80 \%$ & $2.2 \%$ \\
\hline COT & $1.9 \%$ & $2 \%$ & $2.2 \%$ & $2.1 \%$ & $2.6 \%$ & $2.4 \%$ & $2.5 \%$ & $2.4 \%$ & $79.8 \%$ \\
\hline
\end{tabular}

The bold values along the diagonal represent non-migrants within a putative source subpopulation. 
stochastic loss of genetic diversity, besides providing the required alleles to subpopulations under selection that lack favorable genotypes (Kinnison and Hairston, 2007). Although these results allow inferring gene flow between localities, according to Wilson and Rannala (2003) a strong estimate can be reach with a higher sample size per locality. It can be the next goal for further studies, but it is a difficult task to solve immediately because the species is not abundant and is mainly distributed in a preservation area.

According to Fagan et al. (2002, 2005), riverine populations are forecasted to be particularly vulnerable to fragmentation due to their dendritic structure, which may be exacerbated by unidirectional migration. Natural barriers (rapids and waterfalls) and man-made structures, such as dams, also fragment riverine populations, influencing in the dispersal rate and migration pattern (Wofford et al., 2005), even of a rheophilic species of fishes with strong swimming abilities such as G. setequedas (Paiz et al., 2017). However, the construction of a new hydroelectric power plant (Baixo Iguaçu HPP), already underway between the Salto Caxias Reservoir and Iguaçu Falls, could fragment this population preventing the gene flow. As a consequence, there may be loss of genetic diversity and population decline, especially in the area of future reservoir. Moreover, this separate population can be extinguished, as has already happened with another population of $G$. setequedas after the construction of the Itaipu Hydroelectric Power Plant. The disappearance was attributed to the lentic waters of the Itaipu Reservoir, which isolated populations of this rheophilic species, which previously occurred in tributaries of both river banks, in Paraguay and Brazil, and probably in the Paraná River (Paiz et al., 2017).

\section{Conservation Implications}

The abundance, dispersal, and population size are reduced in populations structured by habitat fragmentation due to barriers such as dams, thereby increasing the risk of extinction (Gross et al., 2004; Letcher et al., 2007). This fragmentation can lead to the total or partial isolation of a population, conditioning the response of the individuals. Thus, in the recently found population of $G$. setequedas in the Iguaçu River, a drastic reduction and loss of genetic diversity, due to inbreeding, must be avoided preserving the lotic characteristics of the environment.

For instance, due to the effects of anthropogenic disturbance, small and isolated populations are more likely to suffer loss of genetic diversity and population decline, than a huge population with high genetic diversity (Frankham et al., 2010; Allendorf et al., 2012). According to Frankham (2003), inbreeding reduces reproduction and survival rates, and loss of genetic diversity reduces the ability of populations to evolve to cope with environmental changes, leading to extinction risk.

The type locality and most of the records of G. setequedas are in Paraguay, in tributaries of the right bank of the Paraná river, in the region of influence of the Itaipu reservoir and downstream (Reis et al., 1992). Since the species description, despite several attempts, it was not possible to collect new specimens from the known geographic range of occurrence
(Agostinho et al., 2004; Pavanelli and Reis, 2008). According to Pavanelli and Reis (2008), this species no longer occurs in the Itaipu reservoir, as well as in the floodplain upstream of the reservoir. Despite several collection efforts on the Iguaçu River (Pavanelli and Reis, 2008), mainly in the Lower Iguaçu upstream the National Park (Baumgartner et al., 2012), this species was not collected. For this reason, the conservation status of $G$. setequedas was invariably attributed to a threatened category (Abilhoa and Duboc, 2004; Pavanelli and Reis, 2008; International Union for Conservation of Nature [IUCN], 2014; Paiz et al., 2017). However, recently Paiz et al. (2017) and the present study report the presence of G. setequedas in the Lower Iguaçu in the National Park region. In this way, the population of G. setequedas of the Lower Iguaçu River may be one of the last remnants of this species and, according to Pavanelli and Reis (2008), as G. setequedas is a naturally rare species, it is advisable that any anthropogenic changes in its original ecosystem be discouraged.

The results presented here demonstrate that the population of G. setequedas of the Iguaçu River still maintains satisfactory levels of genetic diversity. However, in terms of conservation management plans, to guarantee the survival of this species, it is necessary to maintain the tributaries of the Iguaçu River and the downstream area from the future reservoir (Baixo Iguaçu Reservoir) without additional dams. Long-term monitoring of genetic diversity and inbreeding could also help conserve this population and provide a basis for future decisions.

\section{ETHICS STATEMENT}

This study was carried out in strict accordance with the recommendations provided in the Guide for the Care and Use of Laboratory Animals. Collection was authorized by the System of Authorization and Information on Biodiversity - SISBIO (SISBIO n ${ }^{\circ}$. 25648-3 and 25648-4), by the Chico Mendes Institute for Biodiversity Conservation ICMBio 003/2014 and Official SEI $n^{\circ}$. 63/2016-DIBIO/ICMBio), and by the Environmental Institute of Paraná - IAP ( $\mathrm{n}^{\circ} .37788$ and 43394). The sampling protocol was approved by the Ethics Committee on the Use of Animals - CEUA of the Universidade Estadual do Oeste do Paraná $\left(n^{\circ}\right.$. 62/09).

\section{AUTHOR CONTRIBUTIONS}

LS-S, DF, MM, and OS designed the research. LA, SP, SM, and MM collected data. LS-S, TK-D, and DF performed the molecular genetic studies. All authors contributed to the writing of the manuscript.

\section{ACKNOWLEDGMENTS}

We are grateful to ICMBio-Parque Nacional do Iguaçu; Consórcio Empreendedor Baixo Iguaçu (CEBI); Universidade Estadual do Oeste do Paraná (UNIOESTE); and Universidade Estadual de Londrina (UEL). 


\section{REFERENCES}

Abdul-Muneer, P. M. (2014). Application of microsatellite markers in conservation genetics and fisheries management: recent advances in population structure analysis and conservation strategies. Genet. Res. Int. 1, 1-11. doi: 10.1155/2014/ 691759

Abell, R., Thieme, M. L., Revenga, C., Bryer, M., Kottelat, M., Bogutskaya, N., et al. (2008). Freshwater ecoregions of the world: a new map of biogeographic units for freshwater biodiversity conservation. BioScience 58, 403-414. doi: 10.1641/ B580507

Abilhoa, V., and Duboc, L. F. (2004). "Peixes," in Livro Vermelho da Fauna Ameaçada no Estado do Paraná, eds S. B. Mikich and R. S. Bérnils (Curitiba: Instituto Ambiental do Paraná), 581-677.

Agostinho, A. A., Thomaz, S. M., and Gomes, L. C. (2004). Threats for biodiversity in the floodplain of the Upper Paraná River: effects of hydrological regulation by dams. Ecohydrol. Hydrobiol. 4, 267-280.

Allendorf, F. W., Luikart, G. H., and Aitken, S. N. (2012). Conservation and the Genetics of Populations. Oxford: Wiley Blackwell Press.

Almeida, F. S., Fungaro, M. H. P., and Sodré, L. M. K. (2001). RAPD and isoenzyme analysis of genetic variability in three allied species of catfish (Siluriformes: Pimelodidae) from the Tibagi River, Brazil. J. Zool. 253, 113-120. doi: 10.1017/ S0952836901000103

Altschul, S. F., Gish, W., Miller, W., Myers, E. W., and Lipman, D. J. (1990). Basic local alignment search tool. J. Mol. Biol. 215, 403-410. doi: 10.1016/S00222836(05)80360- 2

Bandelt, H. J., Forster, P., and Rohl, A. (1999). Median-joining networks for inferring intraspecific phylogenies. Mol. Biol. Evol. 16, 36-48. doi: 10.1093/ oxfordjournals.molbev.a026036

Baumgartner, G., Pavanelli, C. S., Baumgartner, D., Bifi, A. G., Debona, T., and Frana, V. A. (2012). Peixes do Baixo Rio Iguaçu. Maringá: Eduem. doi: 10.7476/ 9788576285861

Beaumont, M. A., and Rannala, B. (2004). The Bayesian revolution in genetics. Nat. Rev. Genet. 5, 251-261. doi: 10.1038/nrg1318

Carvalho-Costa, L. F., Hatanaka, T., and Galetti, P. M. Jr. (2008). Evidence of lack of population substructuring in the Brazilian freshwater fish Prochilodus costatus. Genet. Mol. Biol. 31, 377-380. doi: 10.1590/S1415-475720080002 00036

Cornuet, J. M., and Luikart, G. (1996). Description and power analysis of two tests for detecting recent population bottlenecks from allele frequency data. Genetics 144, 2001-2014.

Cronin, M. A., Spearman, W. J., Wilmot, R. L., and Patton, J. C. (1993). Mitochondrial DNA variation in chinook (Oncorhynchus tshawytscha) and chum salmon (O. keta) detected by restriction enzyme analysis of polymerase chain reaction (PCR) products. Can. J. Fish. Aquat. Sci. 50, 708-715. doi: 10. 1139/f93-081

Cunha, H. A., and Solé-Cava, A. M. (2012). “Análise filogeográfica, in Biologia Molecular e Evolução, eds S. R. Matioli and F. M. C. Fernandes (Ribeirão Preto: Holos), 197-215.

DeWoody, J. A., and Avise, J. C. (2000). Microsatellite variation in marine, freshwater and anadromous fishes compared with other animals. J. Fish Biol. 56, 461-473. doi: 10.1111/j.1095-8649.2000.tb00748.x

Earl, D. A., and VonHoldt, B. M. (2012). STRUCTURE HARVESTER: a website and program for visualizing structure output and implementing the Evanno method. Conserv. Genet. Resour. 4, 359-361. doi: 10.1007/s12686-011-9548-7

Evanno, G., Regnaut, S., and Goudet, J. (2005). Detecting the number of clusters of individuals using the software structure: a simulation study. Mol. Ecol. 14, 2611-2620. doi: 10.1111/j.1365-294X.2005.02553.x

Excoffier, L., and Lischer, H. E. (2010). Arlequin suite ver 3.5: a new series of programs to perform population genetics analyses under Linux and Windows. Mol. Ecol. Resour. 10, 564-567. doi: 10.1111/j.1755-0998.2010.02847.x

Fagan, W. F., Aumann, C., Kennedy, C. M., and Unmack, P. J. (2005). Rarity, fragmentation, and the scale-dependence of extinction-risk in desert fishes. Ecology 86, 34-41. doi: 10.1890/04-0491

Fagan, W. F., Unmack, P. J., Burgess, C., and Minckley, W. L. (2002). Rarity, fragmentation, and extinction risk in desert fishes. Ecology 83, 3250-3256. doi: 10.1890/0012-9658(2002)083[3250:RFAERI]2.0.CO;2

Ferreira, D. G., Galindo, B. A., Alves, A. N., Almeida, F. S., Ruas, C. F., and Sofia, S. H. (2013). Development and characterization of 14 microsatellite loci in the
Neotropical fish Geophagus brasiliensis (Perciformes, Cichlidae). J. Fish Biol. 83, 1430-1438. doi: 10.1111/jfb.12227

Ferreira, D. G., Galindo, B. A., Frantine-Silva, W., Almeida, F. S., and Sofia, S. H. (2015). Genetic structure of a Neotropical sedentary fish revealed by AFLP, microsatellite and mtDNA markers: a case study. Conserv. Genet. 16, 151-166. doi: 10.1007/s10592-014-0648-2

Frankham, R. (2003). Genetics and conservation biology. C. R. Biol. 326, 22-29. doi: 10.1016/S1631-0691(03)00023-4

Frankham, R., Ballou, J. J. D., and Briscoe, D. D. A. (2010). Introduction to Conservation Genetics. New York, NY: Cambridge University Press. doi: 10. 1017/CBO9780511809002

Freeland, J. R. (2005). Molecular Ecology. Chichester: John Wiley \& Sons Ltd.

Fu, Y. X. (1997). Statistical test of neutrality of mutations against population growth, hitchhiking and background selection. Genetics 147, 915-925.

Garcez, R., Calcagnotto, D., and Almeida-Toledo, L. F. (2011). Population structure of the migratory fish Prochilodus lineatus (Characiformes) from Rio Grande basin (Brazil), an area fragmented by dams. Aquat. Conserv. 21, 268-275. doi: $10.1002 /$ aqc. 1176

Goudet, J. (2001). FSTAT, a Program to Estimate and Test Gene Diversities and Fixation Indices (Version 2.9.3). Available at: http://www.unil.ch/dee/ page36921_fr.html [accessed September 3, 2017].

Grant, W. S., and Bowen, B. W. (1998). Shallow population histories in deep evolutionary lineages of marine fishes: insights from sardines e anchovies and lessons for conservation. J. Hered. 89, 415-426. doi: 10.1093/jhered/89. 5.415

Gross, M. C., Schneider, C. H., Matiello, M. C. A., Leite, M. L., Bertollo, L. A. C., and Artoni, R. F. (2004). Population structure, fluctuating asymmetry and genetic variability in an endemic and highly isolated Astyanax fish population (Characidae). Genet. Mol. Biol. 27, 529-535. doi: 10.1590/S141547572004000400011

Hall, T. A. (1999). BioEdit: a user-friendly biological sequence alignment editor and analysis program for Windows 95/98/NT. Nucleic Acids Symp. Ser. 41, 95-98.

Holm, S. (1979). A simple sequentially rejective multiple test procedure. Scand. J. Stat. 6, 65-70.

Hughes, A. R., Inouye, B. D., Johnson, M. T. J., Underwood, N., and Vellend, M. (2008). Ecological consequences of genetic diversity. Ecol. Lett. 11, 609-623. doi: 10.1111/j.1461-0248.2008.01179.x

ICMBio (2017). Lista de Espécies Ameaçadas. Available at: http://www.icmbio.gov. br/portal/especies-ameacadas-destaque

International Union for Conservation of Nature [IUCN] (2014). Standards and Petitions Subcommittee. Guidelines for using the IUCN Red List Categories and Criteria. Version 11. Available at: http://www.iucnredlist.org/technicaldocuments/red-list-training/red-list-guidance-docs

Júlio Júnior, H. F., Bonecker, C., and Agostinho, A. A. (1997). "Reservatório de segredo e sua inserção na bacia do rio Iguaçu," in Reservatório de Segredo: Bases Ecológicas Para o Manejo, eds A. A. Agostinho and L. C. Gomes (Maringá: Eduem), 1-17.

Kinnison, M. T., and Hairston, N. G. (2007). Eco-evolutionary conservation biology: contemporary evolution and the dynamics of persistence. Funct. Ecol. 21, 444-454. doi: 10.1111/j.1365-2435.2007. 01278.x

Letcher, B. H., Nislow, K. H., Coombs, J. A., O'donnell, M. J., and And Dubreuil, T. L. (2007). Population response to habitat fragmentation in a stream-dwelling brook trout population. PLOS ONE 2:e1139. doi: 10.1371/journal.pone.00 01139

Librado, P., and Rozas, J. (2009). DnaSP v5: a software for comprehensive analysis of DNA polymorphism data. Bioinformatics 25, 1451-1452. doi: 10.1093/ bioinformatics/btp187

Liotta, J. (2010). “Antecedentes y propuestas metodológicas para evaluar el estado de conservación de la ictiofauna de la cuenca del plata," in Conservación de los Peces de la Cuenca del Plata en Argentina: Enfoques Metodológicos Para su Evaluación y Manejo, eds J. Cappato, V. De la Balze, J. Peteán, and J. Liotta (Buenos Aires: Fundación para la Conservación y el Uso Sustentable de los Humedales).

Lowe, T. M., and Eddy, S. R. (1997). tRNAscan-SE: a program for improved detection of transfer RNA genes in genomic sequence. Nucleic Acids Res. 25, 955-964. doi: 10.1093/nar/25.5.0955 
Luikart, G., Allendorf, F. W., Cornuet, J. M., and Sherwin, W. B. (1998). Distortion of allele frequency distributions provides a test for recent population bottlenecks. J. Hered. 89, 238-247. doi: 10.1093/jhered/89.3.238

Luikart, G., and Cornuet, J. M. (1998). Empirical evaluation of a test for identifying recently bottlenecked populations from allele frequency data. Conserv. Biol. 12, 228-237. doi: 10.1046/j.1523-1739.1998.96388.x

Maack, R. (1981). Geografia Física do Estado do Paraná. Rio de Janeiro: José Olympio Press.

Maack, R. (2001). Breves notícias sobre a geologia dos estados do Paraná e Santa Catarina. Braz. Arch. Biol. Technol. 169-288. doi: 10.1590/S151689132001000500010

McCusker, M. R., and Bentzen, P. (2010). Positive relationships between genetic diversity and abundance in fishes. Mol. Ecol. 19, 4852-4862. doi: 10.1111/j. 1365-294X.2010.04822.x

Meyer, A., Kocher, T. D., Basasibwaki, P., and Wilson, A. C. (1990). Monophyletic origin of Lake Victoria cichlid fishes suggested by mitochondrial DNA sequences. Nature 347, 550-553. doi: 10.1038/347550a0

Paiz, L. M., Baumgärtner, L., Graça, W. J., Margarido, V. P., and Pavanelli, C. S. (2017). Cytogenetics of Gymnogeophagus setequedas (Cichlidae: Geophaginae), with comments on its geographical distribution. Neotrop. Ichthyol. 15:e160035. doi: 10.1590/1982-0224-20160035

Palstra, F. P., and Ruzzante, D. E. (2008). Genetic estimates of contemporary effective population size: what can they tell us about the importance of genetic stochasticity for wild population persistence? Mol. Ecol. 17, 3428-3447. doi: 10.1111/j.1365-294X.2008. 03842.x

Pavanelli, C. S., and Reis, R. E. (2008). "Gymnogeophagus setequedas," in Livro Vermelho da Fauna Brasileira Ameaçada de Extinção, eds A. B. M. Machado, G. M. Drummond, and A. P. Paglia (Brasília: Fundação Biodiversitas), 184-186.

Piorski, N. M., Sanches, A., Carvalho-Costa, L. F., Hatanaka, T., CarrilloAvila, M., Freitas, P. D., et al. (2008). Contribution of conservation genetics in assessing neotropical freshwater fish biodiversity. Braz. J. Biol. 68, 1039-1050. doi: 10.1590/S1519-69842008000500011

Piry, S., Luikart, G., and Cornuet, J. M. (1999). BOTTLENECK: a computer program for detecting recent reductions in the effective population size using allele frequency data. J. Hered. 90, 502-503. doi: 10.1093/jhered/90. 4.502

Pritchard, J. K., Stephens, M., and Donnelly, P. (2000). Inference of population structure using multilocus genotype data. Genetics 155, 945-959.

Raymond, M., and Rousset, M. (1995). GENEPOP (version 1.2): population genetics software for exact tests and ecumenicism. J. Hered. 86, 248-249. doi: 10.1093/oxfordjournals.jhered.a111573

Reis, R. E., Malabarba, L. R., and Pavanelli, C. S. (1992). Gymnogeophagus setequedas, a new cichlid species (Teleostei: Labroidei) from middle rio Paraná system. Brazil and Paraguay. Ichthyol. Explor. Freshw. 3, 265-272.

Rice, W. R. (1989). Analyzing tables of statistical tests. Evolution 43, 223-225. doi: 10.1111/j.1558-5646.1989.tb04220.x
Rogers, A. R., and Harpending, H. (1992). Population growth makes waves in the distribution of pairwise genetic differences. Mol. Biol. Evol. 9, 552-569.

Rosenberg, N. A. (2004). DISTRUCT: a program for the graphical display of population structure. Mol. Ecol. Notes 4, 137-138. doi: 10.1046/j.1471-8286. 2003.00566.x

Schuelke, M. (2000). An economic method for the fluorescent labeling of PCR fragments. Nat. Biotechnol. 18, 223-234. doi: 10.1038/72708

Slatkin, M., and Hudson, R. R. (1991). Pairwise comparisons of mitochondrial DNA sequences in stable and exponentially growing populations. Genetics 129, $555-562$.

Tajima, F. (1989). Statistical method for testing the neutral mutation hypothesis by DNA polymorphism. Genetics $123,585-595$.

Thompson, J. D., Higgins, D. G., and Gibson, T. J. (1994). Clustal W: improving the sensitivity of progressive multiple sequence alignment through sequence weighting, position-specific gap penalties and weight matrix choice. Nucleic Acids Res. 22, 4673-4680. doi: 10.1093/nar/22.22.4673

Van Oosterhout, C., Hutchinson, W. F., Wills, D. P. M., and Shipley, P. F. (2004). MICRO-CHECKER: software for identifying and correcting genotyping errors in microsatellite data. Mol. Ecol. Notes 4, 535-538. doi: 10.1111/j.1471-8286. 2004.00684.x

Wilson, G. A., and Rannala, B. (2003). Bayesian inference of recent migration rates using multilocus genotypes. Genetics 163, 1177-1191.

Wofford, J. E. B., Gresswell, R. E., and Banks, M. A. (2005). Influence of barriers to movement on within-watershed genetic variation of coastal cutthroat trout. Ecol. Appl. 15, 628-637. doi: 10.1890/04-0095

Wu, F. Q., Shen, S. K., Zhang, X. J., Wang, Y. H., and Sun, W. B. (2015). Genetic diversity and population structure of an extremely endangered species: the world's largest Rhododendron. AoB Plants 7:plu082. doi: 10.1093/aobpla/ plu082

Yeh, F. C., Yang, R., Boyle, T. J., and Xiyan, J. M. (2000). Pop Gene 32: Microsoft Window-Based Freeware for Population Genetic Analysis v.1.32. Edmonton, AB: University of Alberta.

Zawadzki, C. H., Renesto, E., and Bini, L. M. (1999). Genetic and morphometric analysis of three species of the genus Hypostomus Lacépède, 1803 (Osteichthyes: Loricariidae) from the Rio Iguaçu basin (Brazil). Rev. Suisse Zool. 106, 91-105. doi: 10.5962/bhl.part.80072

Conflict of Interest Statement: The authors declare that the research was conducted in the absence of any commercial or financial relationships that could be construed as a potential conflict of interest.

Copyright (C) 2018 Souza-Shibatta, Kotelok-Diniz, Ferreira, Shibatta, Sofia, de Assumpção, Pini, Makrakis and Makrakis. This is an open-access article distributed under the terms of the Creative Commons Attribution License (CC BY). The use, distribution or reproduction in other forums is permitted, provided the original author(s) and the copyright owner are credited and that the original publication in this journal is cited, in accordance with accepted academic practice. No use, distribution or reproduction is permitted which does not comply with these terms. 